WŁODZIMIERZ BIELAK - LUBLIN

\title{
ARCHIWUM PARAFII RZYMSKOKATOLICKIEJ W RYMACZACH (DIECEZJA LUCKA)
}

Wieś Rymacze leży ok. 9,5 km na wschód od Dorohuska (dzisiaj na terenie Ukrainy). Do chwili utworzenia tutaj parafii rzymskokatolickiej w 1925 roku należała do parafii kowelskiej. Przez rok funkcję administratora parafii Rymacze pełnił dziekan kowelski, ks. Jastrzębski.

Pierwszym proboszczem w Rymaczach został ks. Stanisław Brajczewski ${ }^{1}$. Urodził się 24 stycznia 1896 roku w Mianowie, powiat Ostrów, ziemia łomżyńska $^{2}$. Studia seminaryjne rozpoczął w Żytomierzu w 1917 roku. W wyniku rewolucji i wojny polsko-bolszewickiej alumni musieli opuścić seminarium, do którego już nie wrócili. Kleryk Brajczewski znalazł miejsce w seminarium włocławskim $^{3}$. Stamtąd przeniósł się na piąty rok studiów do Gniezna (listopad 1920), dokąd przeniesiono w 1919 roku seminarium łucko-żytomierskie. 19 lutego 1920 roku przyjął święcenia subdiakonatu, a 12 marca tego roku święcenia diakonatu. Obu tym obrzędom przewodniczył bp Kloske. Święceń kapłańskich udzielił dn. Brajczewskiemu bp. Ignacy Dubowski 10 kwietnia 1921 roku w Gnieźnie 4 . Po święceniach ks. Brajczewski pracował jako wikariusz i prefekt w Kowlu, a następnie w Krzemieńcu ${ }^{5}$.

Pod koniec sierpnia 1943 roku, w obawie przed mordami na ludności polskiej dokonywanymi przez Ukraińców na Wołyniu, ks. Brajczewski opuścił swoją pa-

\footnotetext{
${ }^{1}$ Jego krótki biogram autorstwa ks. W. Frątczaka ukazał się w 1989 roku w „Kronice Diecezji Włocławskiej”, 72 (1989) dodatek do nr. 10-11, s. 7-8, ale z pewnymi niedokładnościami co do okres sprzed 1945 roku.

${ }^{2}$ Archiwum Archidiecezji Lubelskiej (dalej AAL), sygn. Dz. IV 22, k. 46: Życiorys ks. Stanisława Brajczewskiego przesłny do Kurii Biskupiej w Lublinie.

${ }^{3}$ [W. Frątczak], Ks. Stanisław Brajczewski, „Kronika Diecezji Włocławskiej”, 72 (1989) dodatek do nr. 10-11, s. 7.

${ }^{4}$ Instytut Archiwów Bibliotek i Muzeów Kościelnych, sygn. Mf ABMK 4227, Akta diecezji łuckiej, Seminarium Łucko-Żytomierskie, s. 35, 44, 48, 51. Por. [Frątczak], Ks. Stanisław Brajczewski, s. 7

${ }^{5}$ [Frątczak], Ks. Stanisław Brajczewski, s. 7; .
} 
rafię i wyjechał do Chełma ${ }^{6}$. Już nigdy nie powrócił do Rymacz na stałe. Prawdopodobnie przez krótki czas dojeżdżał tylko do swej parafii. Ostatni potwierdzony jego pobyt w Rymaczach miał miejsce w niedzielę 5 IX 1943 roku. Odprawił wtedy sumę i zaraz po niej wyjechał?

Do kwietnia 1945 roku ks. Brajczewski był związany z diecezją lubelską. W 1944 roku zastępował proboszcza w Kluczkowicach (kiedy tam przybył? - dokładnie nie wiadomo). Wtedy otrzymał wezwanie od bp. A. Szelążka do powrotu do Rymacz. Wrócić jednak nie chciał, tłumacząc się złym stanem zdrowia. Informował o tym kurię biskupią w Lublinie, prosząc jednocześnie o zgodę na pozostanie $\mathrm{w}$ Kluczkowicach. Zapewne w związku z niepodporządkowaniem się woli biskupa łuckiego zwolniono go $\mathrm{z}$ administrowania parafią kluczkowicką i nie przydzielono żadnego zajęcia zastępczego ${ }^{8}$. Osiadł więc, na bliżej nieokreślonych zasadach, przy kaplicy w Momotach należącej do parafii w Janowie Lubelskim. Stąd pisał prośbę do kurii lubelskiej (29 XI 1944) o uwzględnienie jego kandydatury na proboszcza w parafii Górecko9. Tego stanowiska nie otrzymał, ale został administratorem parafii w Łaszczowie i funkcję tę pełnił do kwietnia 1945 roku. W tym czasie zapewnie rozważał opuszczenie Lubelszczyzny. 2 IV 1945 roku napisał jednozdaniowe pismo do kurii biskupiej: „Niniejszym proszę o zwolnienie mnie z obowiązków administrowania parafią w Łaszczowie dekanatu tomaszowskiego"10. Od tej chwili urywa się jego ślad w diecezji lubelskiej.

Wiadomo jest, że wyjechał do Włocławka i w diecezji kujawsko-kaliskiej pozostał do końca życia. Pracował kolejno w parafiach: Broniszewo (1945-1946), Ostrowąs (1946-1947), Wrząca Wielka (1947-1957), Brudzew Kolski (19571963). Chciał się inkardynować do diecezji włocławskiej, ale sprzeciwił się temu bp A. Szelążek. W 1950 roku został kanonikiem honorowym diecezji łuckiej. Zmarł na zawał serca 6 V 1963 roku w Brudewie. Został pochowany na cmentarzu we Włocławku ${ }^{11}$.

Celowo został przedstawiony życiorys ks. S. Brajczewskiego, bowiem z jego osobą związane są od początku losy archiwum parafii rzymskokatolickiej w Rymaczach. Na początku 2009 roku, przy porządkowaniu archiwum parafii pw. Narodzenia Najświętszej Marii Panny w Chełmie, odnaleziono większą część zasobu archiwalnego parafii rymackiej. Archiwalia te przekazano Instytutowi Archiwów Bibliotek i Muzeów Kościelnych KUL w Lublinie.

Jak on się tam znalazł? Wyjaśnienie jest dość oczywiste. Zabrał go ze sobą proboszcz wyjeżdżając z Rymacz w 1943 roku. Gdy przybył do Chełma, musiał

${ }^{6}$ Według dziekana lubomelskiego, ks. Stefana Jastrzębskiego, przebywał za Bugiem od 30 sierpnia 1943 roku (Pismo dziekana lubomelskiego do bp. A. Szelążka z 8 IX 1943 roku, w: Materiały do dziejów diecezji łuckiej. Relacje o stanie dekanatów i parafii 1941-1944, oprac. M. Dębowska, Biały Dunajec 2005, s. 117).

${ }^{7}$ Pismo dziekana lubomelskiego do bp. A. Szelążka z 9 IX 943 roku, w: Materiaty do dziejów diecezji tuckiej, s. 118.

${ }^{8}$ AAL, sygn. Dz. IV 22, k. 47-48.

${ }^{9}$ Tamże, k. 49.

${ }^{10}$ Tamże, k. 50.

${ }^{11}$ [Frątczak], Ks. Stanisław Brajczewski, s. 8. 
zatrzymać się przy kościele Rozesłania Apostołów, przy którym działały dwie parafie, bowiem kościół na Górce Chełmskiej znajdował się w czasie II wojny światowej w rękach prawosławnych. Tutaj też prawdopodobnie pozostawił dokumenty, które przywiózł ze sobą zza Buga. Gdy w sierpniu 1944 roku kościół mariacki w Chełmie wrócił pod jurysdykcję katolików przeniesiono tam archiwalia należące do parafii Narodzenia NMP. Czy jednak archiwum parafii Rymacze znalazło się wśród nich z powodu związania się ks. Brajczewskiego z tą właśnie parafią, czy uznano, że jako pochodzące ze wschodu tam znajdą właściwsze miejsce, czy wreszcie stało się to przypadkowo? Trudno dziś ustalić przy braku świadków lub wskazówek źródłowych.

Wspomniany zasób obejmuje następujące archiwalia:

Ksieggi metrykalne:

1. Księga egzaminu przedślubnego 1930-1939.

2. Księga nawróconych 1939-1941.

3. Księga metrykalna 1939-1941.

4. Księga protokółów przedślubnych 1927-1929.

5. Raptularz chrztów i zgonów 1936-1940.

6. Raptularz chrztów i zgonów 1933-1935.

7. Książka bierzmowanych 1929-1940.

Inne księgi:

1. Księga statystyczna 1928-1934.

2. Księga statystyczna 1935-1938.

3. Dziennik podawczo-ekspedycyjny 1929-1933.

4. Dziennik podawczo-ekspedycyjny 1933 - 1 IX 1939.

5. Książka kasowa 1937-1940.

6. Książka do zapisywania kwesty zbieranej w niedziele i święta w kaplicy i wydatki na potrzeby tejże kaplicy w Rymaczach 1926-1935.

7. Dziennik kasowy Komitetu Budowy Kościoła Rzymskokatolickiego parafii Rymacze 1928-1929.

T. Korespondencja z kurią biskupią 1921-1939

Zawartość: dokumenty dotyczące ks. Stanisława Brajczewskiego jako wikariusza w Kowlu, dokumenty dotyczące tworzenia parafii w Jagodzinie i później w Rymaczach, różne dokumenty dotyczące parafii w Rymaczach.

T. Korespondencja z księdzem dziekanem

Zawartość: 1. Korespondencja z dziekanem 1924-1943

2. Protokoły wizytacji dziekańskich

\section{T. Komitet Budowy Kościoła}

Zawartość: 1. Protokoły: poszyt protokołów z zebrań Komitetu Budowy Kościoła 1926-1938; protokoły z posiedzeń komisji rewizyjnej 1927; ekspertyza stanu budowy kościoła inż. Fr. Moczula (6 lipca 1929)

2. Umowy zawarte $\mathrm{z}$ wykonawcami 1926-1928;

3. Korespondencja 1927-1934

4. Różne dokumenty 1926-1939. 
T. Sprzedaż lasów 1927-1930

Zawartość: dokumenty dotyczące sprzedaży lasów, wyrębu drewna i wypłaty należności w związku $\mathrm{z}$ budową kościoła w Rymaczach.

T. Wykonanie dzwonów do kościoła 1929-1932

Zawartość: korespondencja z firmą Odlewnia Dzwonów Braci Felczyńskich

T. Ofiary i składki na rzecz parafii Rymacze

Zawartość: 1. Listy dobrowolnych ofiar na budowę kościoła;

2. Wykazy zbierających składki na budowę kościoła;

3. Odezwy w sprawie budowy kościoła ( do Burmistrza miasta Mołodeczno, Naczelnika Wydziału Powiatowego w Chełmie, naczelników Urzędów Powiatowych w Hrubieszowie, Kozienicach, Krasnymstawie,Garwolinie, Starosty Chełmskiego, zawiadowcy stacji kolejowej w Lublinie)

4. Odpowiedzi na odezwy w sprawie budowy kościoła 1927-1929;

5. Listy ofiar w zbożu na budowę kościoła 1935;

6. Lista ofiar na loterię fantową na budowę kościoła;

7. Listy ofiar na rzecz biednych: na paczki wigilijne (1936), w Tygodniu Miłosierdzia (11-23 X 1938);

8. Listy składek na budowę kościoła w zależności od powierzchni posiadanego gruntu 1929-1930 ;

9. Wykaz płatników podatku gruntowego wsi Rymacze 1929;

10. Wykaz ofiar na kościół z racji kolędy 1939.

\section{T. Nieruchomości parafii Rymacze}

Zawartość: 1. Kosztorysy budowy kościoła;

2. Opis kościoła i zabudowań kościelnych;

3. Grunty parafialne;

4. Mapy, plany, projekty, zdjęcia.

\section{T. Budżet parafii}

Zawartość: księga rachunkowa 1926-1927, księga rachunkowa 1936, zestawienie dochodów i wydatków 1 I 1928 - 19 III 1930, projekty budżetu 1932-1939 zatwierdzone przez Kurię Biskupią w Łucku.

T. Listy pasterskie i okólniki 1921-1937.

\section{T. Materiały duszpasterskie}

Zawartość: 1. Notatki ks. Brajczewskiego;

2. Papieskie Dzieło Rozkrzewiania Wiary;

3. Rękopiśmienne teksty pieśni religijnych.

T. Różne druki

\section{T. Czasopisma}

Nietrudno zauważyć, że nie jest to archiwum kompletne - brakuje np. ksiąg metrykalnych, które znajdują się dzisiaj w Urzędzie Stanu Cywilnego m. st. Warszawy (księgi: ochrzczonych, małżeństw i zmarłych z lat 1927-1940).

Obecnie archiwum parafii Rymacze jest porządkowane i zostanie zmikrofilmowane w Instytucie Archiwów Bibliotek i Muzeów Kościelnych. 